\title{
SDHA wt Allele
}

National Cancer Institute

\section{Source}

National Cancer Institute. SDHA wt Allele. NCI Thesaurus. Code C103874.

Human SDHA wild-type allele is located in the vicinity of $5 \mathrm{p} 15$ and is approximately $38 \mathrm{~kb}$ in length. This allele, which encodes succinate dehydrogenase [ubiquinone] flavoprotein subunit, mitochondrial protein, plays a role in cellular respiration. Mutation of the gene is associated with both mitochondrial complex II deficiency and cardiomyopathy dilated type 1GG. 